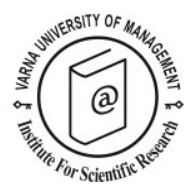

\title{
Tourist loyalty toward shopping destination: the role of shopping satisfaction and destination image
}

\author{
Dwi Suhartanto $^{1 *}$, Ruhadi $^{2}$ and Ni Nyoman Triyuni ${ }^{3}$
}

Received: 23/08/2015 Accepted: 08/11/2015

\footnotetext{
${ }^{1}$ Department of Business Administration, Bandung State Polytechnic, Jl. Gegerkalong Hilir, Ds. Ciwaruga, Bandung, Indonesia; phone: +62 22 2013789; fax: +62 22 2013889; e-mail: dwi.suhartanto@polban.ac.id

${ }^{2}$ Department of Accounting, Bandung State Polytechnic, Indonesia

${ }^{3}$ Department of Tourism, Bali State Polytechnic, Indonesia

* Corresponding author
}

\begin{abstract}
This study extends the theoretical concepts and evaluates the empirical evidence of the relationship between tourist loyalty towards a shopping destination and its two important determinant factors, shopping satisfaction and destination image. The results, drawn from a sample of 563 domestic and foreign tourists in Indonesia, show the importance of tourist shopping satisfaction and destination image as the determinant of tourist loyalty toward a shopping destination. Further, this study discloses that the tourist destination image is the crucial factor in determining tourists' overall shopping satisfaction as well as tourists' loyalty toward the shopping destination. Consequently, the development of a region or a city into a shopping destination is only possible if it simultaneously develops the region or city to be an attractive destination.
\end{abstract}

(C) 2016 Varna University of Management. All rights reserved

Keywords: tourist loyalty, shopping, destination, satisfaction, image.

Citation: Suhartanto, D., Ruhadi and N. Triyuni (2016) Tourist loyalty toward shopping destination: the role of shopping satisfaction and destination image. European Journal of Tourism Research 13, pp. 84-102

\section{Introduction}

Shopping is an important activity for both domestic and foreign tourists. In travelling, tourists purchase a variety of products to meet their own needs during the trip as well as purchases to give as souvenirs to family and friends. The World Tourism Organisation Report on shopping tourism reveals that the average tourist expenditure for shopping is US\$ 920 (accounting for $22.2 \%$ of all tourist expenditure), representing the second largest tourism expenditure after accommodation (UNWTO, 2014). While past studies estimate that average tourists spend for shopping in Hong Kong and Singapore at about 35\% to $50 \%$ (Yeung et al., 2004; Meng and Xu, 2012). With this amount of spending, shopping tourism contributes significantly to the tourism industry. One of the direct economic benefits provided by the shopping sector is that the government 
can increase tax revenues. Further, as shopping is a complex industry consisting of many entities, the development of this sector will boost its derivative businesses such as manufacturing, service providers, and handicraft manufacturers. In addition to promoting the greater economy of the destination (Yeung et al., 2004), the development of a regional shopping destination will also have a positive impact on the image of the destination (Tosun et al., 2007). The researchers also found that shopping is a core contributor to tourist satisfaction and contributes to the overall satisfaction experience with the destination (Rosenbaum and Spears, 2009). In contrast, limiting shopping opportunities in a tourist destination will lessen its attractiveness for tourists to stay longer (Sirakaya-Turk et al., 2015).

Because of the importance of shopping tourism, many tourist destinations are now seriously developing their city or region as a shopping destination (Henderson et al., 2011). As a result, the competition between shopping destinations to attract visitors has now become intense (Yeung et al., 2004; Yoon and Uysal, 2005). In this competitive business, as in any other competitive business environment, an important strategy to survive and flourish is to provide products or services that can satisfy customers and ultimately to create their loyalty (Curran et al., 2010). In this regards, the manager associated with shopping business in a tourist destination and government agencies need to dedicate more resources to increase the satisfaction and loyalty of tourists visiting (Sirakaya-Turk et al., 2015).

Considering the importance of having loyal tourist toward a tourist destination, recent studies have shown interest to examine this issue (Zhang et al., 2014). Some studies have examined destination loyalty in relation with other determinants such as satisfaction, service quality, and destination image (Lin and Lin, 2006; Hui et al., 2007; Zhang et al., 2014). From a theoretical perspective past studies have identified a list of factors encouraging tourists to visit a destination. Past studies have also identified the importance of having loyal tourists towards a destination such as representing the desired market segment (Lau and McKercher, 2004), a longer stay in tourism destinations (Oppermann, 2000), provide positive word-of-mouth, and this leads to lower marketing costs (Neuts et al., 2013). However, although shopping is a popular tourist activity and has become an academic magnet in tourism studies (Yüksel, 2007), studies to scrutinize tourist loyalty towards shopping destination is surprisingly hard to find. Thus, the factors, which lead a tourist to become loyal to a certain shopping destination, clearly need to be uncovered. Based on the review of past studies, Sirakaya-Turk et al. (2015) called for more research into tourist shopping experiences that could help to create destination loyalty. A study to examine the factors that determine tourist loyalty towards a shopping destination is critical as it could provide direction for the development of retail business in a travel destination in particular, as well as the tourism destination itself generally.

This study tries to fill the research gap identified in the literature on tourist shopping loyalty. Specifically, this study attempts to uncover the relationships between tourist loyalty towards a shopping destination and its two determinant factors, shopping satisfaction and destination image. From a theoretical perspective, this study will extend our understanding of the impact of tourist shopping satisfaction on tourist loyalty towards shopping destinations and the effect of destination image on both tourist shopping satisfaction and tourist loyalty towards the shopping destination. Achieving these objectives will extend our understanding of tourist loyalty towards a shopping destination. From a practical perspective, these findings could help retail managers and other shopping tourism stakeholders such as tourism operators, local tourism organisations, and governments to create a sustainable strategy to develop their shopping destination.

\section{Literature Review}

\section{Shopping Destination loyalty}

An important objective of marketing activities is to create customer loyalty toward a product or service to meet the customers demand (Kotler and Armstrong, 2014). Because of its importance, there are a plethora of studies examining customer loyalty, including in a 
tourism context. The study of loyalty can be categorised into three different approaches; behavioural, attitudinal, and composite.

The behavioural approach conceptualised loyalty as a behaviour. Only consumers who purchase a product/service systematically within a certain period are considered loyal customers. In tourism studies, behavioural loyalty was typically measured by the number of visits or the length of stay (Bigne et al., 2001; Alcaniz et al., 2005). Most academics consider this method as being able to give a realistic picture of how the performance of a tourist destination compares to other destinations. However, the usage of this method has been criticised as it lacks a conceptual basis and looks narrowly on what is, in fact, a complex and dynamic set of consumer behaviour (Bloemer et al., 1998). Behavioural loyalty is also criticised as it cannot differentiate a truly loyal customer from consumers who consume for cost or convenience reasons only (Kumar and Shah, 2004). Thus, defining and measuring tourist loyalty towards a shopping destination with this approach is not appropriate.

The second concept in approaching customer loyalty is the attitude approach. In the context of tourism, attitudinal loyalty is described as a psychological expression of tourists' intention to revisit a destination and intention to recommend other prospective tourists (Neuts et al., 2013). Similarly, Yoon and Uysal (2005) contend that attitudinal loyalty is not only observable behaviours but also an intention to buy. In contrast, based on a comprehensive review of past studies on tourism, Zhang et al. (2014) concluded that intention to visit and intention to revisit is classified as a component of behavioural loyalty rather than attitudinal loyalty. This conclusion is in line with the Tripartite Theory of attitude that considers intention to behave as an element of a conative component of attitude (Ajzen, 2005). The use of attitudinal approach is popular because of its ability to allow researchers to uncover the strength of loyalty to a brand from very loyal to the very disloyal (Odin et al., 2001). However, the use of this approach has been criticised for lacking any of the predictive power of the actual behaviour (Bennett and Rundle-Thiele, 2002).
Thus, conceptualizing and measuring tourist loyalty toward shopping destination based on attitudinal approach is also considered inappropriate.

Because of the limitations of both behavioural and attitudinal approaches, many experts in marketing, including tourism, advise a combination of the two approaches. This is known as composite loyalty (Iwasaki and Havitz, 2004). Based on the composite loyalty approach, tourist's loyalty toward a destination is measured by using their actual visit to the destinations as well as their intention to revisit in the future and intention to recommend the destination to others. As a combination of the behavioural and attitudinal approach, the composite approach could provide a comprehensive understanding of tourist loyalty. This approach could also provide a sound result in understanding past, current, and future of tourist loyalty (Zhang et al., 2014). Thus, in this study, tourist loyalty towards a shopping destination is conceptualised as a composite loyalty; that is tourist visitation to a certain shopping destination, as well as their intention to revisit again in the future and to recommend the shopping destination to others.

\section{Shopping satisfaction}

Over the last thirty years, tourist satisfaction has become one of the central issues in tourism studies (Hui et al., 2007) and various definitions of tourist satisfaction have been proposed. Although several definitions have been proposed by scholars, most, if not all of these definitions, acknowledge that customer satisfaction is complex, which includes cognitive, affective, and psychological and physiological undiscovered dynamics (Bhattacharya and Singh, 2008; Oliver, 2010). Satisfying the customer is an important element in the marketing of tourism destinations because of its influence on the behaviour of tourists and purchase of products or services in the future (Yoon and Uysal, 2005; Hui et al., 2007) and the rate of profit and stock value (Anderson, et al., 2004). There is little doubt that understanding tourist satisfaction is a critical aspect in building a sustainable tourism industry (Ekinci et al., 2008). 
Tourist loyalty toward shopping destination: the role of shopping satisfaction and destination image.

Because of the significance of customer satisfaction in determining the success of the business, many theories have been constructed to explain this construct. These theories include the ExpectationDisconfirmation, Equity Theory, and Comparison-Level Theory (Skogland and Siguaw, 2004) and Disconfirmation Expectancy Theory is arguably the most influential and has received the widest acceptance due to its broad applicability conceptualisation (Yeung et al., 2004). Expectancy-Disconfirmation theory explains the formation of expectations and disconfirmation of expectations by comparing its performance. The expectation is a perception of pre-consumption related to products or services consumed while the performance is the basis of consumer perceptions of products or services consumed. Disconfirmation arises from the discrepancy between prior expectation and actual performance of the goods and services. This disconfirmation concept occupies a central position as a crucial intervening variable in the Expectancy - Disconfirmation Paradigm. If a customer perceives that the quality of the product or service that he or she buys exceeds their needs, wants, and expectations, then customer satisfaction will be high (positive disconfirmation). Alternatively, if a customer perceives that the quality of the product or service does not meet their needs, wants, and expectations, then, customer satisfaction will be low (negative disconfirmation).

Tourist satisfaction research in various tourism contexts can be grouped into two streams. The first stream is research that measures the level of tourist satisfaction and identifies the shortfall of the service delivery (Yeung et al., 2004; LeHew and Wesley, 2007; Tosun et al., 2007; Lin and Lin, 2010). These tourist satisfaction researchers tend to use the univariate model and are more for managerial purposes as they are diagnostic in nature. The second stream of tourist satisfaction research tends to use multivariate model comprising several determinant variables such as motivation (Yoon and Uysal, 2005; Sirakaya-Turk et al., 2015), attitude (Meng and $\mathrm{Xu}, 2012$ ), service quality (Juwaheer, 2004; Hui et al., 2007), image (Faullant et al., 2008) as well as its consequences, such as tourist intentions (Yoon and Uysal, 2005; Li and Petrick, 2010), and actual tourist behaviour (Meng and $\mathrm{Xu}, 2012$ ). Overall, researchers in this stream have shown that tourist satisfaction not only determines tourist loyalty, but also mediates the relationships between service quality, motivation value, and destination image on tourist loyalty. However, previous researches are still unable to convincingly clarify the complex relationship between tourist satisfaction and tourist loyalty. Thus, it is important that tourist' shopping satisfaction is included as one of the determinants of tourist loyalty towards shopping destination.

\section{Destination image}

The destination image is an important variable in marketing. Besides having an important role in decision-making and subsequent tourist behaviour, this factor has been explored extensively in the literature in the context of tourism (Pike, 2002). The destination image is a person's perception of aspects of attributes and holistically made by the destination (Echtner and Ritchie, 1991). In a similar manner, Kim and Richardson (2003) defines the destination image as an overall impression, belief, idea, and hope, and feelings about a place that is accumulated within a certain time. There are several definitions of destination image but all concede that it is a complex concept more than a summation of all the factual attributes of a destination.

Some researchers argue that the consumer experience in consuming the products or services as well as promotional strategies such as advertising, public relations, shape the image of a destination in the consumers' mind (Lee et al., 2008). In addition, the consumer is being influenced by experience and its determinants such as promotion, brand image and also formed through association with other entities such as country, person, place, or event (Park et al., 1996). Image is influenced by the interactions between these determinants that are both factual and emotionally associated with a destination (Dobni and Zinkhan, 1990). Among these factors, some argue that a tourists' direct experience with the product or service in a destination is the most important aspect. Brand image is conceptually recognised as an important determinant of 
Attribute of Shopping

Satisfaction



Figure 1. Framework Shopping Destination Loyalty Model

brand loyalty. Past studies have integrated this important variable in examinations of brand loyalty in the context of a tourist destination (Chi and Qu, 2008; Chi, 2012; Zhang et al., 2014). However, integration of this concept in understanding tourist loyalty towards shopping destination is difficult to find. Thus, extending the model of tourist loyalty towards shopping destination to include the destination image as one of its determinants is both logical and inevitable.

\section{Proposed Model and Hypotheses}

This study attempts to reveal the relationships between tourist loyalty, tourist satisfaction, and destination image in the context of a shopping destination. Based on the reviewed literature, to answer this objective, the model of the relationship between the three constructs is illustrated in Figure 1.

Following the earlier discussion on the available literature, the proposed model is developed based on merging three wellestablished theories of customer satisfaction (disconfirmation paradigm), brand loyalty (cognition, affection, and behavioural), and holistic image theory. The model proposes that overall satisfaction is determined by satisfaction with the shopping attributes; while overall satisfaction and destination image simultaneously affect destination loyalty (both attitudinal and behavioural). In this model, the overall satisfaction mediates the link between satisfaction with shopping attributes and destination loyalty (both attitudinal and behavioural). However, as the purpose of the study tries to explore the role of tourist satisfaction and destination image, the mediation role of overall satisfaction was not specifically addressed.

Following previous studies (Hui et al., 2007; Chi, 2012), tourist satisfaction consists of two parts, satisfaction with shopping attributes and overall shopping satisfaction. Tourist satisfaction with shopping attributes consists of five factors, namely, value, service, convenience, attractiveness, and accessibility (Yeung et al., 2004; Lin and Lin, 2006; LeHew and Wesley, 2007; Hurst and Niehm, 2012). All of these shopping attributes directly affect overall tourist satisfaction and indirectly affect attitudinal and behavioural loyalty. Based on this conceptual framework, the following hypotheses on satisfaction with shopping attributes were drawn in this study.

H1: Satisfaction with value attribute positively influences overall satisfaction.

$\mathrm{H} 2$ : Satisfaction with service attribute positively influences overall satisfaction.

H3: Satisfaction with convenience attribute positively influences overall satisfaction.

H4: Satisfaction with attractiveness attribute positively influences overall satisfaction. 
Tourist loyalty toward shopping destination: the role of shopping satisfaction and destination image.

H5: Satisfaction with accessibility attribute positively influences overall satisfaction.

Past studies examining the relationship between brand image, customer satisfaction, and brand loyalty in various service industries indicate that brand image tends to influence positively on both customer satisfaction and brand loyalty (Lai et al., 2009; Choi et al., 2011; Suhartanto et al., 2013). Thus, it is suggested that destination image affects the tourists' overall shopping satisfaction and directly and indirectly affects tourist loyalty. Finally, the positive association between attitudinal loyalty and behavioural loyalty has been established in the literature (Zhang et al., 2014). Based on this conceptual framework, the following hypotheses were depicted in this study.

H6: Destination image positively influences overall satisfaction

H7: Destination image positively influences attitudinal loyalty

H8: Destination image positively influences behavioural loyalty

H9: Overall shopping satisfaction positively influences attitudinal loyalty

H10: Overall shopping satisfaction positively influences behavioural loyalty

H11: Attitudinal loyalty positively influences behavioural loyalty

\section{Research Method \\ Sample}

The empirical data for this research was gathered by using self-administered questionnaires from both domestic and foreign tourists who were shopping for fashion products in Indonesia. The respondents were approached during their shopping activities in malls and shopping centres located in Bandung and Denpasar City [Bali]. Both cities are popular tourist destinations as regional shopping destinations in Indonesia. As there are domestic and foreign tourists, questionnaires were constructed in two languages, Indonesian and English. Prior to collecting the data, the questionnaire was pretested to obtain feedback on the clarity and appropriateness of the questions to ensure its suitability for the research purpose. In the data collection process, to warrant that the shopper approached was a tourist, he or she was asked whether he or she was a tourist or a resident, before being given the questionnaire.

A few considerations were used to decide the sample size of this study. The generally acceptable rule of thumb for the least amount of sample size in SEM-PLS analysis is ten times the highest number of indicators used (Hair et al., 2014). Using this approach, at least 40 samples are needed since the highest number of variable indicators is 4 (satisfaction with attractiveness attribute). However, using this rule of thumb for determining the minimum sample size in PLS can cause low levels of statistical power (Henseler et al., 2009). Using the research purposes as a consideration, Malhotra and Birks (2007) maintain that sample size between $300-500$ is suitable for research intended for problem-solving. Lastly, Hair et al. (2014) contend that a larger sample sizes could increase the precision (i.e., consistency) of SEM-PLS estimations. Using these considerations, the 563 usable sample collected is considered as acceptable to test the proposed model.

\section{Measurement}

The study of shopping satisfaction, destination image and destination loyalty have been carried-out widely. Thus, the questionnaire used existing literature as a basis and then modified such questionnaires to fit the research purposes as well as the target population. Satisfaction with shopping attributes consists of 5 factors (value, service, convenience, attractiveness, and accessibility) and was measured using 14 items (see Table 2) adapted from previous shopping literature (Yeung et al., 2004; Lin and Lin, 2006; LeHew and Wesley, 2007; Hurst and Niehm, 2012). As the literature on shopping attributes have been widely discussed, and the scales have been relatively established, exploratory factor analysis was not conducted (Costello and Osborne, 2005).

The confirmation of these shopping attributes was conducted in the measurement model. This study uses a disconfirmation paradigm approach to measure tourists' shopping satisfaction. Thus, the 14 items were used to measure tourist perception and expectation on the shopping attributes. The expectations were measured by the 5 Likert-type scale ( 1 not 
important and 5 very important), while perceptions was measured by 5 Likert-type scale ( 1 very poor and 5 very good). Following Chi (2012), overall satisfaction is gauged by one item, measured by 5 Likert-type scale ( 1 very unsatisfied and 5 very satisfied).

This study treats the destination image as an overall image which was conceptualised as holistic tourist impression of the destination. Following Bigne et al. (2001), this study measures destination image with a single holistic item, measured by 5 Likert-type scale ( 1 very poor, 5 very good). The measurement of destination image uses a single item, often criticised for making it difficult to determine the underlying dimensions (Zhang et al., 2014). However, this approach is quite popular among tourism scholars (Choi et al., 2011) due to its concurrent validity which is not significantly different from using multiple items for measurement (Dolnicar and Grun, 2013). For this reason, in addition to facilitating the the respondents' ability to respond simply, this study measures overall image destination with one item.

The variable of tourist loyalty towards the shopping destination was operationalised as a composite loyalty consisting of attitudinal loyalty and behavioural loyalty [refer to Zhang et al. (2014)], attitudinal loyalty is measured by one question of tourist intention to recommend the shopping destination, measured by 5 Likerttype scale (1 very unlikely and 5 very likely). Behavioural loyalty is gauged with 2 items, tourist intention to revisit the destination to shop in the future, measured by 5 Likert-type scale (1 very unlikely and 5 very likely) and tourist frequency of shopping, measured by 3 scale ( $<3$ times, 3-5 times, and more than 5 times).

\section{Data Analysis}

Prior to testing the proposed model, checking multivariate data indicates that the data was not normally distributed. Thus, the assumptions for using covariance-based structural equation modelling (SEM) to test the proposed shopping loyalty model was not satisfied. Therefore, the estimation of the measurement model and the structural proposed model were conducted using partial least squares (PLS). The usage of this method was due to its ability to handle nonmultivariate normal data and multicollinearity among independent variables (Hair et al., 2010). The other reason of using this variancebased SEM (PLS) is due to the objective of this study, which tries to explore the relationships among constructs and to measure the predictive validity of the exogenous variable (Peng and Lai, 2012; Hair et al., 2014). When the purpose of a study is to confirm a theory and the data was not normally distributed, testing the proposed model using a variancebased SEM (PLS) is considered as appropriate (Hair et al., 2012).

\section{Data Analysis and Result}

Description of the Respondents

Of the total 563 respondents, 173 respondents $(30.7 \%)$ visited for the purpose of shopping and 390 respondents visited for the purpose other than shopping (recreation, business, family visit, and others). The demographic characteristics of the respondents are depicted in Table 1.

This research applies the disconfirmationexpectation approach as the method of measuring customer satisfaction at five attributes of the shopping experience. The respondents' expectation and perception of the items to measure the shopping satisfaction is depicted in Table 2.

Table 2 illustrates the finding of the respondents' expectation of the 5 shopping attributes (14 items) tested. The paired t-test was conducted to examine the significant differences between mean expectation and mean perception. This study applies the disconfirmation-expectation paradigm approach. If the tourist perception mean on a certain item is higher than its expectation mean and its t-value is significant $(p<5 \%)$, this indicates that the respondent is satisfied with the items. On the contrary, if the perception mean of an attribute is lower than its expectation mean and its t-value is significant $(p<5 \%)$, this indicates that the respondent is dissatisfied with the attribute. The result of testing differences between expectation and perception (Table 2) shows that all items of the attribute of value, service, and convenience the respondent were dissatisfied. In the attribute of 
Tourist loyalty toward shopping destination: the role of shopping satisfaction and destination image.

Table 1. Demographic Characteristics of the Respondents

\begin{tabular}{llll}
\hline Variable & Description & Frequency & $\%$ \\
\hline Main purpose of visit & Shopping & 173 & 30.7 \\
& Non-shopping & 388 & 69.3 \\
& - Recreation & 173 & 30.7 \\
& - Business & 88 & 15.6 \\
& - Family Visit & 68 & 12.1 \\
& - Others & 59 & 10.5 \\
\hline Gender & Male & 262 & 46.5 \\
& Female & 298 & 52.9 \\
\hline Age & $17-25$ years & 176 & 31.3 \\
& $25-35$ years & 180 & 32.0 \\
& 36 - 45 years & 114 & 20.2 \\
\hline Education & Over 45 years & 87 & 15.5 \\
& Less than high school & 40 & 7.1 \\
& High school & 139 & 24.7 \\
& Bachelor & 300 & 53.3 \\
\hline Type of Tourist & Post Graduate & 73 & 13.0 \\
\hline & Domestic & 466 & 82.8 \\
\hline
\end{tabular}

Table 2. Expectation and Perception on Shopping attributes

\begin{tabular}{|c|c|c|c|c|c|c|}
\hline \multirow[t]{2}{*}{ Shopping Attribute } & \multicolumn{2}{|c|}{ Expectation } & \multirow{2}{*}{\multicolumn{2}{|c|}{ Perception }} & \multirow{2}{*}{$\begin{array}{l}\text { Mean } \\
\text { Diff }\end{array}$} & \multirow[b]{2}{*}{ t-Value } \\
\hline & Mean & Std. Dev & Mean & & & \\
\hline \multicolumn{7}{|l|}{ Value } \\
\hline - Product quality & 4.300 & 0.710 & 3.870 & 0.591 & -0.430 & $11.826^{* \star}$ \\
\hline - Product price & 3.940 & 0.917 & 3.700 & 0.686 & -0.240 & $5.103^{* *}$ \\
\hline - Discount & 4.070 & 0.995 & 3.600 & 0.876 & -0.471 & $9.771^{* *}$ \\
\hline \multicolumn{7}{|l|}{ Service } \\
\hline - Service of store staff & 3.740 & 0.605 & 4.230 & 0.748 & -0.490 & $13.412^{\star \star}$ \\
\hline - Knowledge of store staff & 4.090 & 0.848 & 3.760 & 0.684 & -0.336 & $8.466^{\star \star}$ \\
\hline \multicolumn{7}{|l|}{ Convenience } \\
\hline - Safety of shopping & 4.510 & 0.641 & 3.890 & 0.683 & -0.596 & $16.649^{\star \star}$ \\
\hline - Cleanliness of the shopping area & 4.090 & 0.781 & 3.760 & 0.687 & -0.323 & $8.043^{\star *}$ \\
\hline - Convenience of shopping & 4.250 & 0.749 & 3.920 & 0.741 & -0.333 & $9.949^{\star *}$ \\
\hline \multicolumn{7}{|l|}{ Attractiveness } \\
\hline - Display of product & 3.700 & 0.923 & 3.700 & 0.701 & 0.002 & -0.046 \\
\hline - Product brand & 3.520 & 0.967 & 3.720 & 0.663 & 0.208 & $-4.754^{* *}$ \\
\hline - Product variety & 3.900 & 0.797 & 3.890 & 0.645 & -0.020 & 0.495 \\
\hline - Uniqueness of product & 3.910 & 0.857 & 3.830 & 0.715 & -0.025 & $1.993^{*}$ \\
\hline \multicolumn{7}{|l|}{ Accessibility } \\
\hline - Traffic to/from shopping location & & & & & & \\
\hline - Location of shopping & 3.680 & 0.824 & 3.780 & 0.647 & 0.101 & $-2.426^{*}$ \\
\hline
\end{tabular}

Note: ${ }^{\star \star}$ Significant at $p<1 \%,{ }^{*}$ Significant at $p<5 \%$

attractiveness, respondents were divided into satisfied with the item of a product brand, dissatisfied with the items uniqueness of the product, and neither satisfied nor dissatisfied with the items of display product and product variety. Finally, with the accessibility attribute, respondents were satisfied with the item of location shopping but dissatisfied with the item of traffic to/from shopping location.

Overall, among items tested, Table 2 shows that the respondents were most dissatisfied with traffic to/from shopping location. This dissatisfying factor is not surprising as the traffic in the cities where data was collected is relatively problematic. Following traffic, the respondents were dissatisfied with safety, service, and discount items. On the contrary, respondents tend to feel satisfied with product brand and location of shopping.

\section{Measurement Model}

The first stage in testing the model is to assess the validity (both convergent and discriminant validity) and reliability of the constructs. The convergent validity was evaluated through factor loadings and average variance extracted (AVE) (Hair et al. 2010). Anderson and Gerbing 
(1988) claimed that convergent validity could be assessed by determining whether each indicator's estimated coefficient on the underlying construct is significant, with threshold criterion is 0.5 . Table 3 shows that, except the items of display of product and frequency of visit, all of the value of standardised loading of all items used in the measurement of research variables are significant $(p<1 \%)$ and above 0.5 . This result shows that both items are not valid indicators; thus they were excluded from further analysis. With the exclusion of the frequency of visit, the variable behavioural loyalty is only measured by using the indicators of intention to revisit.
Measurement of behavioural loyalty with one item is not considered problematic since a single measurement item of loyalty is also an effective method and common measurement of loyalty (Reichheld, 2003).

Discriminant validity was evaluated based on cross loading and Monotrait Heterotrait Ratio (HTMT) test as proposed by scholars (Hair et al., 2010; Henseler et al., 2015). The result of cross loading test for validity discriminant is shown in Table 4.

Table 4 reveals that all items as a measure of the variables used in the research have the

Table 3. Loading of the Item Measurement, Composite Reliability (CR) and AVE

\begin{tabular}{|c|c|c|c|}
\hline Construct/ltem & Loading* & CR & AVE \\
\hline Satisfaction with Value & & 0.744 & 0.614 \\
\hline - Product quality (Val1) & 0.673 & & \\
\hline - Product price (Val2) & 0.832 & & \\
\hline - Discount (Val3) & 0.588 & & \\
\hline Satisfaction with Service & & 0.824 & 0.701 \\
\hline - Service of store staff (Ser1) & 0.801 & & \\
\hline - Knowledge of store staff (Ser2) & 0.873 & & \\
\hline Satisfaction with Convenience & & 0.837 & 0.633 \\
\hline - Safety of shopping (Con1) & 0.866 & & \\
\hline - Cleanliness of the shopping area (Con2) & 0.690 & & \\
\hline - Convenience of shopping (Con3) & 0.820 & & \\
\hline Satisfaction with Attractiveness & & 0.777 & 0.541 \\
\hline - Product brand (Att1) & 0.599 & & \\
\hline - Product variety (Att2) & 0.800 & & \\
\hline - Uniqueness of product (Att3) & 0.779 & & \\
\hline - Display of product (Att4) & 0.446 & & \\
\hline Satisfaction with Accessibility & & 0.759 & 0.614 \\
\hline - Traffic to/from shopping location (Ass1) & 0.712 & & \\
\hline - Location of shopping (Ass2) & 0.849 & & \\
\hline \multicolumn{4}{|l|}{ Behavioural Loyalty } \\
\hline - Intention to re-shop in the future & 264.006 & 264.006 & 264.006 \\
\hline - Frequency of visit & 0.183 & 0.183 & 0.183 \\
\hline
\end{tabular}

Note: *All significant at $p<1 \%$

Table 4. Cross Loading Indicators

\begin{tabular}{llllll}
\hline Item & Value & Service & Convenience & Attractiveness & Accessibility \\
\hline Val1 & $\mathbf{0 . 5 8 8}$ & 0.311 & 0.306 & 0.243 & 0.223 \\
Val2 & $\mathbf{0 . 8 3 2}$ & 0.138 & 0.203 & 0.131 & 0.123 \\
Val3 & $\mathbf{0 . 6 7 3}$ & 0.190 & 0.330 & 0.192 & 0.194 \\
Ser1 & 0.205 & $\mathbf{0 . 8 0 1}$ & 0.411 & 0.215 & 0.309 \\
Ser2 & 0.260 & $\mathbf{0 . 8 7 3}$ & 0.420 & 0.332 & 0.306 \\
Con1 & 0.244 & 0.351 & $\mathbf{0 . 6 9 0}$ & 0.236 & 0.331 \\
Con2 & 0.338 & 0.374 & $\mathbf{0 . 8 2 0}$ & 0.276 & 0.288 \\
Con3 & 0.321 & 0.441 & $\mathbf{0 . 8 6 6}$ & 0.283 & 0.273 \\
Att1 & 0.248 & 0.242 & 0.264 & $\mathbf{0 . 5 9 9}$ & 0.325 \\
Att2 & 0.213 & 0.232 & 0.219 & $\mathbf{0 . 8 0 0}$ & 0.377 \\
Att3 & 0.080 & 0.226 & 0.242 & $\mathbf{0 . 7 7 9}$ & 0.219 \\
Att4 & 0.217 & 0.283 & 0.196 & $\mathbf{0 . 4 4 6}$ & 0.157 \\
Acc1 & 0.194 & 0.327 & 0.322 & 0.175 & $\mathbf{0 . 7 1 2}$ \\
Acc2 & 0.186 & 0.260 & 0.275 & 0.439 & $\mathbf{0 . 8 4 9}$ \\
\hline
\end{tabular}


greatest loading value of the variables intended to measure compared to other variables. In other words, all items used to measure a variable have higher proximity than the proximity with other variables. Furthermore, Table 5 shows that the discriminant validity of the variables used in this study is valid because there is no value for HTMT greater than 0.9 (Henseler et al., 2015).

The reliability of the constructs was assessed based on composite reliability. Cronbach' Alpha test of reliability, commonly used to test reliability test, uses the assumption that all items have equal loading and have the same variance (Hair et al., 2010). In practice, these assumptions would be extremely difficult to meet, so the use of this method for estimating reliability construct is often a problem (Yang and Green, 2011). Thus, in this study the reliability was tested by using composite reliability rather than Cronbach' Alpha. As shown in Table 3, the result of the composite reliability test points-out that the tourist shopping satisfaction attributes are reliable, as its values are well over the suggested level of 0.7 (Henseler et al., 2009).

\section{Structural Model}

The structural model and hypotheses tests were conducted by using SmartPLS 3.0. A bootstrapping procedure with 500 iterations was conducted to assess the statistical significance of the weights of indicators and the path coefficients (Hair et al., 2014). To assess of model fit, the corrected $R^{2}$ of all constructs were estimated to employ a diagnostic tool. The GoF measure applies the geometric mean of the communality and the average $R^{2}$ for endogenous constructs. Daryanto et al. (2010) report the values for assessing the results of the GoF analysis as follow: small, 0.02; medium, 0.25; and large, 0.36. For the complete model in this study, a GoF value of 0.388 (see Table 6) indicates that tourist loyalty toward a destination model performs well. These findings indicate that the proposed loyalty toward shopping destination model is fit to explain the data.

Chin et al. (2008) contend that the researcher can use the magnitude of $R^{2}$ and the predictive sample reuse technique Stone-Geisser's $Q^{2}$ value as a criterion for the predictive relevance of testing model using PLS. Using blindfolding

Table 5. Heterotrait-Monotrait Ratio

\begin{tabular}{lcccccccc} 
& BHL & ATL & OSA & DIM & ACC & ATT & CON & SER \\
\hline Behavioural Loyalty (BHL) & & & & & & & & \\
Attitudinal Loyalty (ATL) & 0.657 & & & & & & & \\
Overall Satisfaction (OSA) & 0.321 & 0.309 & & & & & & \\
Destination Image (DIM) & 0.297 & 0.254 & 0.337 & & & & & \\
Accessibility (ACC) & 0.173 & 0.138 & 0.284 & 0.263 & & & & \\
Attractiveness (ATT) & 0.131 & 0.130 & 0.281 & 0.120 & 0.860 & & & \\
Convenience (CON) & 0.078 & 0.042 & 0.257 & 0.121 & 0.738 & 0.524 & & \\
Service (SER) & 0.097 & 0.073 & 0.206 & 0.199 & 0.802 & 0.548 & 0.768 & \\
Value (VAL) & 0.082 & 0.115 & 0.282 & 0.082 & 0.602 & 0.501 & 0.679 & 0.565 \\
\hline
\end{tabular}

Table 6. Goodness of Fit (GoF) Index

\begin{tabular}{|c|c|c|c|}
\hline Variable & AVE & $R^{2}$ & \\
\hline Value & 0.500 & & \\
\hline Service & 0.701 & & \\
\hline Convenience & 0.633 & & \\
\hline Attractiveness & 0.541 & & \\
\hline Accessibility & 0.614 & & \\
\hline Overall Satisfaction & & 0.177 & \\
\hline Attitudinal Loyalty & & 0.121 & \\
\hline Behavioural Loyalty & & 0.458 & \\
\hline Average score & 0.598 & 0.252 & \\
\hline AVE $\times R^{2}$ & & & 0.151 \\
\hline GoF $=\sqrt{ }\left(\mathrm{AVE} \times R^{2}\right)$ & & & 0.388 \\
\hline
\end{tabular}


procedure, $\mathrm{Q}^{2}$ indicates how well the data can be restructured using model and the parameters of PLS (Ali et al., 2015). The cut-off value of $Q^{2}$ is greater than 0 indicates that the model tested has predictive relevance, while the value less than 0 indicates the lack of predictive value (Hair et al., 2014). The results of $\mathrm{Q}^{2}$ calculation are $0.612,0.113,0.170$ for overall satisfaction, attitudinal loyalty, and behavioural loyalty respectively, indicating that they have satisfactorily predictive relevance.

The result of testing the structural model depicted in Figure 2 shows the standardised coefficient while the corrected $R^{2}$ values, indicating the explanatory power of the predicator variable(s) on the particular construct, is depicted in parentheses. The shopping attributes explain $17.7 \%$ of tourist overall satisfaction with the shopping. Overall satisfaction and destination image explain $12.1 \%\left(R^{2}=0.121\right)$ attitudinal loyalty, whereas overall satisfaction, destination image, and attitudinal loyalty explain $45.8 \%\left(R^{2}=0.458\right)$ of behavioural loyalty. Chin et al. (2008) classified $R^{2}$ values of endogenous latent variables into

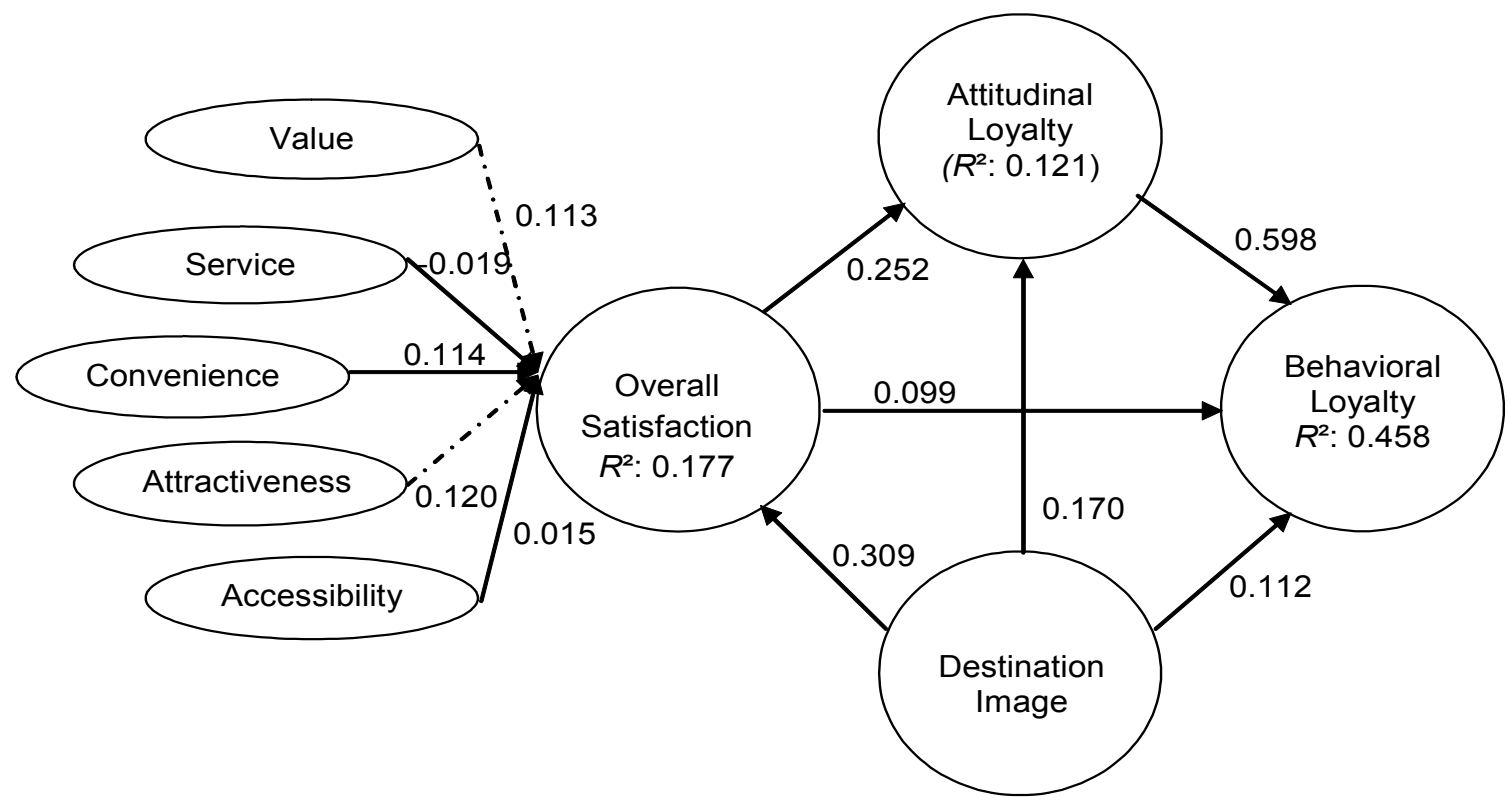

Not significant

Figure 2. Summary of Tested Model

Table 7. Path Coefficient

\begin{tabular}{llll}
\hline Path & Coefficient & t-value & Decision \\
\hline Value => Overall Satisfaction & 0.113 & $2.045^{*}$ & Supported \\
Service => Overall Satisfaction & -0.019 & 0.408 & Not Supported \\
Convenience => Overall Satisfaction & 0.114 & $2.528^{*}$ & Supported \\
Attractiveness => Overall Satisfaction & 0.120 & $2.515^{*}$ & Supported \\
Accessibility => Overall Satisfaction & 0.015 & 0.311 & Not Supported \\
Destination Image => Overall Satisfaction & 0.309 & $6.100^{* *}$ & Supported \\
Overall Satisfaction => Attitudinal Loyalty & 0.252 & $4.491^{* *}$ & Supported \\
Overall Satisfaction => Behavioural Loyalty & 0.099 & $2.444^{*}$ & Supported \\
Destination Image => Attitudinal Loyalty & 0.170 & $2.855^{* *}$ & Supported \\
Destination Image => Behavioural Loyalty & 0.112 & $2.418^{*}$ & Supported \\
Attitudinal Loyalty => Behavioural Loyalty & 0.598 & $14.342^{* *}$ & Supported \\
\hline
\end{tabular}

Note: *Significant at $p<0.05$; ${ }^{* *}$ Significant at $p<0.01$. 
three types: 0.67 (substantial), 0.33 (moderate), and 0.19 (weak). Based on this classification, overall satisfaction $\left(R^{2}=0.177\right)$ and attitudinal loyalty $\left(R^{2}=0.121\right)$ is weak, while behavioural loyalty $\left(R^{2}=0.458\right)$ is in between moderate and substantial. The low value of $R^{2}$ for overall satisfaction and attitudinal loyalty indicates that the predictor(s) explain little variability of the dependent variables, something which is common in tourism studies (Ali et al., 2015).

Table 7 depicts the estimation results for the hypothesised conceptual framework for tourist loyalty towards shopping destination.

Hypotheses 1 to 5 postulated the relationships between satisfaction with shopping attributes (value, service, convenience, attractiveness, and accessibility) and tourist overall shopping satisfaction. Table 7 shows that of the five attributes of shopping satisfaction, three attributes (value, convenience, and attractiveness) are positive and significantly related to tourist overall shopping satisfaction, as their coefficients are significant at $p<1 \%$ (attractiveness and convenience) and $p<5 \%$ (value). While the effect of attribute accessibility and service does not significantly influence the overall tourist shopping satisfaction.

Hypotheses 6 to 8 investigate the effect of shopping destination image on overall tourist shopping satisfaction, tourist attitudinal loyalty (intention to recommend the shopping destination), and behavioural loyalty (intention to revisit the shopping destination in the future). The result of the testing the model (Table 7) indicates that all of the paths tested are significant. The path between destination image and overall shopping satisfaction $(0,309)$ and path between destination image and attitudinal loyalty $(0.170)$ are significant at $p<1 \%$; while the path between destination image and behavioural loyalty $(0.112)$ is significant at $p<5 \%$. Thus, there is a support for the hypothesis $\mathrm{H} 6, \mathrm{H} 7$, and $\mathrm{H} 8$.

Hypothesis 9 postulated the effect of overall satisfaction with the shopping attributes on attitudinal loyalty, while Hypotheses $\mathrm{H} 10$ postulated the effect of overall shopping satisfaction on tourist behavioural loyalty. Table 7 shows that both coefficient paths are significant at $p<1 \%$ (the path of overall satisfaction and attitudinal loyalty with coefficient 0.252 ) and $p<5 \%$ (path between satisfaction and behavioural loyalty with coefficient 0.099). Lastly, this study confirms the established relationships between attitudinal loyalty and behavioural loyalty, as the path between these variables (coefficient 0.598 ) is significant at $p<1 \%$; thus, support for hypothesis $\mathrm{H} 11$ is provided.

\section{Multi-Group Analysis}

The characteristic of the respondent (Table 1) shows that the respondent can be classified into several groups based on gender, type of tourist, and tourist purpose of the visit. To check the consistency of tourist loyalty towards shopping destination model tested, multi-group analyses based on these three sub-respondent groups (male and female, domestic and foreign tourist, and shopping and non-shopping purpose of visit) were conducted as recommended by scholars (Henseler et al., 2015).

The results of the PLS multi-group analyses (Table 8) show that only the path between destination image and overall satisfaction (based on the purpose of visit) and between overall satisfaction and behavioural loyalty (based on the type of tourist type), are significant; while the other paths are not significant across the group analysis. The coefficient path between destination image and overall satisfaction in the model of shopping purpose of visit sub-samples is 0.438 and in the model of tourism shopper sub-sample is 0.268 , both are significant at $p<5 \%$. The path between overall satisfaction and behavioural loyalty on the model of domestic tourist subsample (coefficient 0.102) is significant at $\mathrm{p}<5 \%$, but not significant in the model of foreign tourist sub-sample (coefficient -0.119). These results indicate that, in overall, the relationships between the constructs differ minimally between the groups tested.

\section{The Effects of the Variables}

To get a better understanding of the relationship between variables tested in the model, it is necessary that this study conduct 
Table 8. Multi-Group Analysis

\begin{tabular}{lccc}
\hline Path & \multicolumn{3}{c}{ Coefficient Differences } \\
\cline { 2 - 4 } & \multirow{2}{*}{ Gender } & $\begin{array}{c}\text { Type of } \\
\text { Tourist }\end{array}$ & $\begin{array}{c}\text { Purpose of } \\
\text { Visit }\end{array}$ \\
\hline Accessibility => Overall Satisfaction & 0.181 & 0.089 & 0.053 \\
Attractiveness => Overall Satisfaction & 0.093 & 0.101 & 0.105 \\
Convenience => Overall Satisfaction & 0.090 & 0.020 & 0.062 \\
Service => Overall Satisfaction & 0.093 & 0.059 & 0.065 \\
Value => Overall Satisfaction & 0.117 & 0.124 & 0.031 \\
Destination Image => Overall Satisfaction & 0.025 & 0.278 & $0.170^{*}$ \\
Destination Image => Attitudinal Loyalty & 0.076 & 0.179 & 0.037 \\
Destination Image => Behavioural Loyalty & 0.099 & 0.201 & 0.126 \\
Overall Satisfaction => Attitudinal Loyalty & 0.170 & 0.107 & 0.104 \\
Overall Satisfaction => Behavioural Loyalty & 0.188 & $0.205^{\star *}$ & 0.047 \\
Attitudinal Loyalty => Behavioural Loyalty & 0.003 & 0.151 & 0.017 \\
\hline Not
\end{tabular}

Note: ${ }^{* *}$ Significant at $p<1 \%,{ }^{*}$ Significant at $p<5 \%$

Table 9. Total Effect and Indirect Effect of Variables

\begin{tabular}{llccc}
\hline Variable & Effect & $\begin{array}{c}\text { Overall } \\
\text { Satisfaction }\end{array}$ & $\begin{array}{c}\text { Attitudinal } \\
\text { Loyalty }\end{array}$ & $\begin{array}{c}\text { Behavioural } \\
\text { Loyalty }\end{array}$ \\
\hline \multirow{2}{*}{ Accessibility } & Total & 0.015 & 0.004 & 0.004 \\
& Indirect & - & 0.004 & 0.004 \\
\hline \multirow{2}{*}{ Attractiveness } & Total & 0.120 & 0.030 & 0.030 \\
& Indirect & - & 0.030 & 0.030 \\
\hline \multirow{2}{*}{ Convenience } & Total & 0.114 & 0.029 & 0.029 \\
& Indirect & - & 0.029 & 0.029 \\
\hline \multirow{2}{*}{ Service } & Total & -0.019 & -0.005 & -0.005 \\
& Indirect & - & -0.005 & -0.005 \\
\hline \multirow{2}{*}{ Value } & Total & 0.113 & 0.028 & 0.028 \\
& Indirect & - & 0.028 & 0.028 \\
\hline \multirow{2}{*}{ Destination Image } & Total & 0.309 & 0.248 & 0.290 \\
& Indirect & - & 0.078 & 0.179 \\
\hline \multirow{2}{*}{ Overall Satisfaction } & Total & - & 0.252 & 0.249 \\
& Indirect & - & - & 0.150 \\
\hline Attitudinal Loyalty & Total & - & - & 0.598 \\
\hline
\end{tabular}

the effect variable test. Kline (2005) contends that there are two effects, direct effect (the influence of a variable to another variable that is not mediated by other variables) and indirect effect (the effect of one that is mediated by at least one other variable). The sum of indirect and direct effects of the variables is total effect. The indirect effect is estimated statistically from the standardised direct effects that comprise them. Based on the summary of the testing loyalty model (Figure 2), the indirect and the total effect of exogenous variables (satisfaction with the attribute of shopping attributes, destination image, overall satisfaction, and attitudinal loyalty) on the endogenous variables (overall satisfaction, attitudinal loyalty, and behavioural loyalty) is reported in Table 9.

Table 9 highlights several important findings on the effects of satisfaction with shopping attributes and destination image on endogenous variables. Satisfaction with shopping attributes on attitudinal loyalty and behavioural loyalty has a very limited indirect effect, ranging between -0.005 and 0.003 . While the direct effect of satisfaction with shopping attributes has a bigger range between -0.019 and 0.120 . Further, the total effect of overall satisfaction on tourist attitudinal loyalty and behavioural loyalty is 0.252 and 0.249 respectively. These findings indicate that satisfaction with attributes has limited effect on whether a tourist will be loyal towards a shopping destination. This result implies that the effect of satisfaction of shopping attributes effect on tourist loyalty on shopping destination is through overall satisfaction with the shopping experience as indicated the high direct effect of overall satisfaction on attitudinal loyalty $(0.252)$ and behavioural loyalty (0.249). The total 
impact of destination image on overall satisfaction, attitudinal loyalty, and behavioural loyalty is between 0.248 and 0.309 . This finding highlights the importance of destination image as a determinant of tourist loyalty towards a shopping destination compared to tourist shopping satisfaction. Finally, the positive direct effect of attitudinal loyalty on behavioural loyalty providing a support for previous studies (Chi, 2012; Zhang et al., 2014).

\section{Discussion}

Tourism literature clearly indicates that destination loyalty is an imperative factor in the development of the tourism industry (Zhang et al., 2014; Sirakaya-Turk et al., 2015). Further, previous studies in the context of tourism found that tourist satisfaction and destination image are important determinants of tourist loyalty towards a destination (Faullant et al., 2008; Chi, 2012; Neuts et al., 2013; Zhang et al., 2014); however, those studies focused on loyalty toward vacation destination. None of the previous studies has examined the effect of these loyalty determinants on tourist loyalty towards a shopping destination. The purpose of this study is to scrutinize the model of the relationship between tourist shopping satisfaction, destination image, and tourist loyalty towards a shopping destination. The findings of this study contribute to our theoretical understanding of the formation of tourist loyalty towards a shopping destination.

This research highlights the importance of tourist shopping satisfaction and destination image as the determinant of tourist loyalty towards shopping destination. Specifically, both tourist satisfaction and destination image make a significant contribution to the tourists' intention to recommend the shopping destination and the tourists' intention to revisit the destination to shop in the future. This finding becomes an important issue as it expands our understanding from a theoretical perspective of how tourist loyalty towards shopping destination is formed, something that is still rarely understood. Furthermore, the shopping destination model testing results also confirms the relationships between tourist satisfaction, destination image, and tourist loyalty towards a tourism destination (Bigne et al., 2001; Zhang et al., 2014; Fung and Jim,
2015). Satisfying the tourist shopping experience and developing a positive image as a destination clearly are important strategic marketing issues to develop a city or region as a shopping destination. Thus, investing resources to increase both a destination image on tourist perception and providing an excellent shopping experience, will pay great dividends to shopping destination managers.

Testing on tourist loyalty towards the shopping destination model reveals that the tourist destination image is a critical factor in influencing tourists overall shopping satisfaction as well as tourist loyalty toward shopping destination. In other words, the tourists' perception of the city or region as a shopping destination will determine whether the tourist will consider recommending and revisiting the destination to shop in the future. These findings imply that, shopping affects the tourists' experience of the city as a tourist destination. The negative experience with the city as a destination would lessen the tourist satisfaction and their intention to visit and shop there in the future. Because the aspects of a city as a tourist destination is very complex and covers many aspects, these findings provide direction and guidance for governments, authorities and other stakeholders in the development of shopping destinations. The development of a tourist destination based solely on shopping aspect only, such as the availability of attractive shops or the availability of merchandise discounts will be less effective to attract tourists to visit and shop. The development of a city or region into a shopping destination could only be possible if it simultaneously also develops the city or region to be an attractive destination.

From the modelling test, it appears that the tourist satisfaction with accessibility attribute (measured by traffic to and from shopping destinations and shopping locations) and service attribute (measured with service store and knowledge of store staff) does not significantly affect overall shopping satisfaction. The possible explanation of this finding is that in most major cities in Indonesia, including in Bandung and Denpasar, traffic is poor, although it is an important factor to attract tourists to visit (Hurst and Niehm, 2012; Meng 
and $\mathrm{Xu}, 2012$ ), this poor traffic condition will affect how tourist reach the shopping location. As there is no choice for tourists to choose shopping destination with any relatively good traffic condition, their expectation on traffic is relatively low. Thus, even though they tend to be unsatisfied with the traffic, this factor will not affect their overall satisfaction.

In terms of service attribute, the insignificance of this factor on influencing the tourists overall satisfaction is most likely because the tourists are more concerned about the product they have bought. Thus, no matter the level of service that they get, as long as the product they bought matches their expectation, they tend to feel satisfied with their shopping experience. The implication of this finding highlights the importance of business managers to provide products that meet with tourist needs.

One other important finding from the data analysis is the gap between expectations and perception of traffic to and from shopping destinations. It shows that the gap between perception and expectation on traffic is the highest compared to that of other shopping attributes. This finding indicates that the tourist is most unsatisfied with this factor. It should be noted from the modelling test that traffic (together with shopping location) is not an important part of the model when influencing both tourist overall satisfaction and loyalty. A possible explanation for this finding is that traffic, though important, is something that is 'unavoidable' by tourists as most of the major cities in Indonesia which have similar traffic problems. For example, tourists who are not satisfied with the traffic in Bandung have almost no choice looking for a shopping destination in other cities such as Jakarta or Surabaya as these cities also face similar traffic problems. Due to these conditions, despite the high tourist expectations, this factor may have little effect when deciding whether to recommend or revisit the shopping destination again in the future.

To sump-up, the current study offers strong evidence that tourist satisfaction and the destination image directly affect tourist loyalty towards a shopping destination. However, although existing research is providing support to the linkage between tourist shopping satisfaction and destination image as a determinant of tourist loyalty towards a shopping destination, it is not conclusive. The current study finds that having satisfaction with the shopping attributes may well be necessary although the image of the shopping destination continues to play a significant part in developing tourist loyalty towards a shopping destination.

\section{Managerial implications}

Shopping tourism now has flourished, and steep competition occurred not only between retail entities but also between the shopping destinations to attract tourists (Yeung et al. 2004; LeHew and Wesley, 2007; Chi and Qu, 2008). Thus, it is important to improve our understanding of the reasons tourist are loyal towards a shopping destination and the factors that drive them to be loyal to the shopping destination. The findings of this study provide important managerial consequences for retail managers as well as for government agencies.

The results of the data analysis provide guidance to develop tourist loyalty towards a shopping destination. This study discloses that destination image is a key factor in determining tourist loyalty towards a shopping destination as it has a direct effect on the tourist shopping experience. Therefore, shopping destination managers must develop unique and positive images for tourist of their shopping destination if they want their destination to compete effectively in the competitive shopping tourist market.

An image in the customers' mind is not easy to change, thus the destination managers and government agencies need to present the right image in the first place of their shopping destination. Although it is difficult to control all factors influencing image, it is possible to manipulate the destination image through promotion strategy of the shopping retail entities as well as the shopping destination itself. The promotion strategy to attract tourist visiting the destination such as creating regular sales events to appeal to tourists is an important approach. 
Beside each component of the destination, the destination as a whole also influences the image of a shopping destination. Thus, administering quality offered by tourism entities such as restaurants, tourist attractions, hotel, and providing an excellent city infrastructure are important factors to develop an image of a shopping destination. In short, the shopping destination managers and government agencies must carefully develop and maintain their destination image as well as maintain the high quality of their product and services they offer as those factors influence tourist shopping satisfaction and their future shopping loyalty behaviour.

Shopping destination managers recognise the role of tourist satisfaction in advancing tourist shopping destination loyalty. If tourist are satisfied with his/her shopping experience, it is most likely that he/she is more eager to revisit the destination for shopping and spread positive word-of-mouth recommendation about the destination. This study provides confirmation of this assumption that satisfaction has direct effect on tourist loyalty towards a shopping destination, both attitudinal and behavioural. Higher tourist shopping satisfaction with their shopping experience will result in higher loyalty towards a shopping destination. Thus, the retail managers and government agencies of a shopping destination should concentrate on developing high level of tourist satisfaction in order to initiate tourist positive post-purchase behaviour and increase the shopping destinations' competitiveness.

This study reveals that tourist satisfaction with shopping attributes consists of 5 latent dimensions (value, service convenience, attractiveness, and accessibility) with the attributes of value, convenience, and attractiveness as the significant factors in determining tourist overall satisfaction with the shopping experience. This finding could help retail managers in a shopping destination to understand better the factors contributing to tourist satisfaction with the shopping experience and their loyalty towards shopping destination. Understanding this issue will help the managers to deliver appropriate products, price, and an attractive and convenience shop to accommodate tourist need and want
Therefore, retail managers should consider the practical applications of these latent variables, which are essential elements in developing tourist' overall satisfaction with their shopping experience and finally affect their loyalty toward a city or a region as a shopping destination. Additionally, to achieve a high overall level of satisfaction, it is suggested that all stakeholders involved in the development of a city or region as a shopping destination, effectively coordinate their strategies in providing high value offerings and provide convenient and attractive retail entities.

\section{Limitations and Recommendations}

This study provides empirical evidence concerning tourist loyalty towards the shopping destination model in Indonesia. However, this study does not assure similar findings when the model is tested in a different shopping destination as different shopping destinations might have different characteristics. Because of the importance of this loyalty model in understanding and developing a shopping destination, further testing on tourist loyalty for specific destination models needs to be conducted in different locations. With testing in other locations, our understanding of tourist loyalty towards the shopping destination will be more defined.

This study uses two main factors in the literature that affect customer loyalty, namely customer satisfaction and image factors. Because there are other factors that influence customer loyalty, such as service quality and value, it is necessarily that a further testing needs to include these aspects as the antecedent of tourist loyalty towards a shopping destination. This may reveal omissions and falsification of the interactions tested in the present shopping destination loyalty model and further theoretical enhancement and extension.

This research shows the importance of how the destination image affects tourist loyalty to a tourist destination shopping. In this study, the destination image is measured with one item. Because the destination image is a complex construct, it is unclear which aspects that govern and which do not affect tourist satisfaction and loyalty towards a shopping 
destination. It is suggested that future studies use more inclusive and psychometrically sound instruments of destination image that would reinforce the reliability of the results and help advance the research in tourism shopping.

\section{References}

Ajzen, I. (2005) Attitude, personality, and behavior (2nd ed.): Open University Press.

Alcaniz, E., I. Garcia, S. Blas (2005) Relationships among residents' image, evaluation of the stay and post-purchase behaviour. Journal of Vacation Marketing, 11(4), 291-302.

Ali, F., M. Amin, C. Cobanoglu (2015) An Integrated Model of Service Experience, Emotions, Satisfaction, and Price Acceptance: An Empirical Analysis in the Chinese Hospitality Industry. Journal of Hospitality Marketing \& Management (forthcoming).

Ali, F., K. Ryu, K. Hussain (2015) Influence of experiences on memories, satisfaction and behavioral intentions: A study of creative tourism. Journal of Travel \& Tourism Marketing, (forthcoming).

Anderson, E., C. Fornell, S. Mazvancheryl (2004) Customer satisfaction and shareholder value. Journal of Marketing, 68(4), 172-185.

Anderson, J., D. Gerbing (1988) Structural equation modeling in practice: A review and recommended two-step approach. Psychological Bulletin, 103(3), 411-423.

Bennett, R., S. Rundle-Thiele (2002) A comparison of attitudinal loyalty measurement approaches. Journal of Brand Management, 9(3), 193-209.

Bhattacharya, S., D. Singh (2008) The emergence of hierarchy in customer perceived value for services: A grounded analysis. Journal of American Academy of Business, 13(65), 28-49.

Bigne, J, M. Sanchez, J. Sanchez (2001) Tourism image, evaluation variables and after purchase behaviour: Interrelationship. Tourism Management, 22(6), 607-616.

Bloemer, J., K. Ruyter, P. Peeters (1998) Investigating drivers of bank loyalty: The complex relationship between image, service quality and satisfaction. The
International Journal of Bank Marketing, 16(7), 276-286.

Chi, C. (2012) An examination of destination loyalty: Differences between first-time and repeat visitors Journal of Hospitality \& Tourism Research, 36(1), 3-24.

Chi, C., H. Qu (2008) Examining the structural relationships of destination image, tourist satisfaction and destination loyalty: An integrated approach. Tourism Management, 29, 624-636.

Chin, W., R. Peterson, S. Brown (2008) Structural equation modeling in marketing: Some practical reminders. Journal of Marketing Theory and Practice, 16(4), 287-293.

Choi, J. G., T. Tkachenko, S. Sil, J. Cohen (2011) On the destination image of Korea by Russian tourists. Tourism Management, 32(1), 193-194.

Costello, A., J. Osborne (2005) Best practices in exploratory factor analysis: Four recommendations for getting the most from your analysis. Practical Assessment Research \& Evaluation, 10 (7), 1-9.

Curran, J., S. Varki, D. Rosen (2010) Loyalty and its antecedents: Are the relationships static? Journal of Relationship Marketing, 9(4), 179-199.

Daryanto, A., K. de Ruyter, M. Wetzels (2010) Getting a Discount or Sharing the Cost: The Influence of Regulatory Fit on Consumer Response to Service Pricing Schemes. Journal of Service Research, 13(2), 153-167.

Dobni, D., G. Zinkhan (1990) In search of brand image: A foundation analysis. Advances in Consumer Research, 17, 110-119.

Dolnicar, S., B. Grun (2013) Validity measuring destination image in survey studies. Journal of Travel Research, 52(1), 3-14.

Echtner, C., J. Ritchie (1991) The meaning and measurement of destination image. Journal of Tourism Studies, 2(2), 2-12.

Ekinci, Y., G. Massey, P. Dawes (2008) An extended model of the antecedents and consequences of consumer satisfaction for hospitality services. European Journal of Marketing, 42, 35-68.

Faullant, R., K. Matzler, J. Füller (2008) The impact of satisfaction and image on 
Tourist loyalty toward shopping destination: the role of shopping satisfaction and destination image.

loyalty: The case of Alpine ski resorts. Managing Service Quality, 18, 163-178.

Fung, C., C. Jim (2015) Segmentation by motivation of Hong Kong Global Geopark visitors in relation to sustainable naturebased tourism. International Journal of Sustainable Development \& World Ecology, 22(1), 76-88.

Hair, J., G. Hult, C. Ringle, M. Sarstedt (2014) A Primer on Partial Least Squares Structural Equation Modeling (PLS-SEM). Los Angeles: Sage.

Hair, J., W. Black, B. Babin, R. Anderson (2010) Multivariate data analysis: A global perspective (7th Ed.). Upper Saddle River: Pearson Education.

Hair, J., M. Sarstedt, C. Ringle, J. Mena (2012) An assessment of the use of partial least squares structural equation modeling in marketing research. Journal of the Academy Marketing Science, 40, 414-433.

Henderson, J., L. Chee, C. Mun, C. Lee (2011) Shopping, tourism, and retailing in Singapore. Managing Leisure, 16, 36-48.

Henseler, J., C. Ringle, M. Sarstedt (2015) A new criterion for assessing discriminant validity in variance-based structural equation modeling. Journal of the Academy of Marketing Science, 43(1), 115-135.

Henseler, J., C. Ringle, R. Sinkovics (2009) The use of partial least square path modeling in international marketing. Advances in International Marketing, 20, 277-319.

Hui, T., D. Wan, A. Ho (2007) Tourists' satisfaction, recommendation and revisiting Singapore. Tourism Management, 28, 965-975.

Hurst, J., L. Niehm (2012) Tourism shopping in rural markets: A case study in rural lowa. International Journal of Culture, Tourism, and Hospitality Research, 6(3), 194-208.

Iwasaki, Y., M. Havitz (2004) Examining relationships between leisure involvement, psychological commitment and loyalty to a recreation agency. Journal of Leisure Research, 36(1), 45-72.

Juwaheer, T. (2004) Exploring international tourists' perceptions of hotel operations by using a modified SERVQUAL approach - a case study of Mauritius. Managing Service Quality, 14, 350-364.
Kim, H., S. Richardson (2003) Motion picture impacts on destination images. Annals of Tourism Research, 30(1), 216-237.

Kline, R. (2005) Principles and practice of structural equation modeling (2nd Ed.). New York: The Guilford Press.

Kotler, P., G. Armstrong (2014) Principles of marketing $\left(15^{\text {th }}\right.$ Ed.). Upper Saddle River, NJ Pearson.

Kumar, V., D. Shah (2004) Building and sustaining profitable customer loyalty for the 21st century. Journal of Retailing, 80(4), 317-329.

Lai, F., M. Griffin, B. Babin (2009) How quality, value, image, and satisfaction create loyalty at a Chinese telecom. Journal of Business Research (62), 980-997.

Lau, L., B. McKercher (2004) Exploration versus consumption: a comparison of firsttime and repeat tourists. Journal of Travel Research, 42, 279-285.

Lee, M., D. Knight, Y. Kim (2008) Brand analysis of a US global brand in comparison with domestic brands in Mexico, Korea, and Japan. The Journal of Product and Brand Management, 17(3), 163-174.

LeHew, M., S. Wesley (2007) Tourist shoppers' satisfaction with regional shopping mall experiences. International Journal of Culture, Tourism, and Hospitality Research, 1(1), 82-96.

Li, X., J. Petrick (2010) Revisiting the Commitment-Loyalty Distinction in a Cruising Context. Journal of Leisure Research, 42(1), 67-89.

Lin, C., Y. Lin (2010) Internal and external marketing for exotic restaurants. Journal of Foodservice Business Research, 13(3), 193-216.

Lin, Y., K. Lin (2006) Assessing mainland Chinese visitors' satisfaction with shopping in Taiwan. Asia Pacific Journal of Tourism Research, 11(3), 247-259.

Malhotra, N., D. Birks (2007) Marketing Research: An Applied Approach (3rd Ed.). New Jersey: Prentice Hall. .

Meng, F., Y. Xu (2012) Tourism shopping behavior: planned, impulsive, or experiential? International Journal of Culture, Tourism and Hospitality Research, 6(3), 250-265. 
Neuts, B., J. Romão, E. van Leeuwen, P. Nijkamp (2013) Describing the relationships between tourist satisfaction and destination loyalty in a segmented and digitalized market. Unpublished manuscript.

Odin, Y., N. Odin, P. Valette-Florence (2001) Conceptual and operational aspects of brand loyalty: An empirical investigation. Journal of Business Research, 53(2), 7584.

Oliver, R. (2010) Satisfaction: A Behavioral Perspective on the Consumer (2nd Ed.). New York: Wiley.

Oppermann, M. (2000) Tourism destination loyalty. Journal of Travel Research, 39(1), 78-84.

Park, C., S. Jun, A. Shocker (1996) Composite branding alliances: An investigation of extension and feedback effects. Journal of Marketing Research, 33(4), 453-466.

Peng, D., F. Lai (2012) Using partial least squares in operations management research: A practical guideline and summary of past research. Journal of Operations Management, 30, 467-480.

Pike, S. (2002) Destination image analysis review of 142 papers from 1973 to 2000. Tourism Management, 23(5), 541-549.

Reichheld, F. (2003) The one number you need to grow. Harvard Business Review, 81(12), 46-54.

Rosenbaum, M., D. Spears (2009) Using group comparisons in AMOS to explore shopping as a travel driver. International Journal of Culture, Tourism, and Hospitality Research, 3(4), 313-325.

Sirakaya-Turk, E., Y. Ekinci, M. Martin (2015) The efficacy of shopping value in predicting destination loyalty. Journal of Business Research (forthcoming).
Skogland, I., J. Siguaw (2004) Are your satisfied customers loyal? Cornell Hotel and Restaurant Administration Quarterly, 45, 221-234.

Suhartanto, D., M. Clemes, D. Dean (2013) Analyzing the Complex and Dynamic Nature of Brand Loyalty in the Hotel Industry. Tourism Review International, 17(1), 47-61

Tosun, C., P. Temizkan, D. Timothy, A. Fyall (2007) Tourist shopping experience and satisfaction. International Journal of Tourism Research, 9, 87-102.

UNWTO. (2014) Global Report on Shopping Tourism. Spain: World Tourist Organisation.

Yang, Y., S. Green (2011) Coefficient alpha: A reliability coefficient for the 21st century? Journal of Psychoeducational Assessment, 29(4), 377 - 392.

Yeung, S., J. Wong, E. Ko (2004) Preferred shopping motivation: Hong Kong versus Singapore. International Journal of Tourism Research, 6, 85-96.

Yoon, Y., M. Uysal (2005) An examination of the effects of motivation and satisfaction on destination loyalty: A structural model. Tourism Management, 26, 45-56.

Yüksel, A. (2007) Tourist shopping habitat: Effects on emotions, shopping value and behaviours. Tourism Management, 28(1), 58-69.

Zhang, H., X. Fu, L. Cai, L. Lu (2014) Destination image and tourist loyalty: $A$ meta-analysis. Tourism Management, 40, 213-223. 